\title{
Modeling the relationship between achieving the sustainable development goals on the example of the Russian Federation
}

\author{
Ekaterina Fedorovna Shamaeva*, Elena Sergeevna Surskova \\ Dubna State University, 141980, Dubna, 19 Universitetskaya Str., Russia
}

\begin{abstract}
The article is devoted to the analysis of the peculiarities of achieving the Sustainable Development Goals (SDGs) and its assessment at the national level. The Goals developed by the UN General Assembly in 2015 are a strategy to conserve economic and environmental resources, reduce inequality and meet the needs of population in the present and future realities. Importance of achieving the SDGs is due to the possibilities for improving the socio-economic situation in Russia. This paper focuses on the Sustainable Development Goal on achieving inclusive and equitable quality education and promoting lifelong learning opportunities for all (SDG4). The multilevel implementation of the Goals, as well as the complexity of its monitoring, form the need for a thorough analysis and development of approaches to assessing the SDG targets achievement. The article presents the dynamics of the Sustainable Development Goals, offers techniques for normalization and modeling the relationship of achieving the Sustainable Development Goals using correlation analysis and mentioning the methodology for constructing a regression model.
\end{abstract}

\section{Introduction}

The UN conceptual documents contain the long-term sustainable development goals (SDGs) approved at the UN conference in 2015 and set for the period from 2016 to 2030 for all countries of the world. The Sustainable Development Goals have replaced the widely recognized Millennium Development Goals (2000-2015) aimed at solving social, environmental and economic problems [S.N. Bobylev, p. 26]. Achieving the SDGs involves overcoming systemic and structural barriers to sustainable development, the development of all countries with a certain variation. Despite the fact that representatives of the Russian Federation have taken steps towards achieving the SDGs, at the national level there are still no clearly developed approaches to their implementation and an adaptive strategy for sustainable development [A.G. Sakharov, pp. 191-192]. At the moment, a lot of domestic studies are devoted to the issues and problems of achieving the SDGs [Agranovich M.L., 2017], [Bobylev S.N., 2017], [Kuznetsov O.L., 2001], [Lanshina T.A., 2019], [Linders A.M.R., 2020], [Maltsev A.A, 2020], [Sakharov A.G., 2019], [Smirnova T.S.,

\footnotetext{
* Corresponding author: $\underline{b b @ u n i-d u b n a . r u}$
} 
2019], as well as papers of foreign authors Barbier E. B., 2017], [Diemer A., 2020], [Lawrence A. W., 2020], [Mondal S., 2021], [Saito O., 2017], [Raitskaya L., 2021].

Ensuring inclusive and equitable quality education and encouraging lifelong learning opportunities for all is one of the 17 sustainable development goals (SDG4) that is actively considered by the scientific community [Agranovich M.L., 2017], [Kamyshanov V.I., 2016], [Milovantseva N.M., 2018].

Achieving the Sustainable Development Goal in education at the national level is important in terms of forming the basis for improving the socio-economic situation. The existing difficulties in monitoring and achieving SDG4 [13] create the need to analyze and develop new approaches, as well as the conditions within which the assessment of achievement of planned indicators shall take place. In order to comprehensively achieve SDG4, as well as to identify hidden trends in this article, we offer a model for assessing the education sector through a set of indicators of the Sustainable Development Goals. The main goal of this paper is to model achievement of the Sustainable Development Goals and their interrelationships at the national level.

\section{Theoretical and Methodological Part}

Formation of the concept of sustainable development dates back to the beginning of 1987, when the Brundtland Commission report sounded the definition of sustainable development as development that allows "current generations to meet their needs without compromising the opportunities of future generations" [T.A. Lanshina, p. 208]. In 2000, eight Millennium Development Goals (MDGs) were formulated, the action of which is designed for 20002015 , and is aimed at solving social and economic problems in many countries of the world. The end of the MDGs predetermined the need to implement new mechanisms to continue work in these areas, which became the basis for development of 17 Sustainable Development Goals (SDGs) adopted within the framework of "Agenda for Sustainable Development up to 2030".

The SDGs contain several main aspects of development: social, economic and environmental, aimed at solving the global problems of the countries of the world. The existing problems in the implementation of the Goals are usually associated with the unevenness of the social and economic development of countries, as well as the lack of financial resources [T.S. Smirnova, p. 22]. Achievement of SDG4 is a basis conducive to improving the socio-economic living conditions of the population and a key element for achieving many other Sustainable Development Goals. In this sense, studying the relationship between SDG4 and the rest of the Goals, as well as identifying hidden trends and problem areas for their implementation, requires use of certain metrics for their assessment. One of the methods of assessment is the normalization method, the types of which are as follows [T.V. Gavrilova, p. 3]:

1. The ranking (ordinal) method is the ranking of variables according to some principle.

2. Linear scaling method is transformation of values in which they are located in the range (min, $\max$ ).

3. The scoring method is the assessment of variables using the assignment of reference points in an expert way.

To study the relationship between achievement of the SDGs, the most appropriate is use of correlation analysis, which allows to determine the strength and direction of the relationship between the variables [A.M. Grzhibovsky, pp. 50-51]. Traditionally, statistics distinguish the following types of correlation analysis [E.G. Spodareva, p. 28]:

1. Pairwise correlation dependence is the relationship between the effective and factorial indicator, or two factorial indicator. 
2. Private correlation dependence is the relationship between the effective and factorial indicator.

3. Multiple correlation dependence is the relationship between the effective and two or more factor indicators.

Exploring the relationship between achievement of the SDGs based on the results of correlation analysis can be useful to understand the impact of SDG4 on other Goals, as well as increase the relevance of collecting quality data and implementing each of them.

\section{Data and Methods}

Formation of the assessment model involves implementation of several stages, namely:

1. Selection of quantitative SDG data.

2. Normalization of indicators.

3. Calculation of the integral value for each of the goals.

4. Correlation analysis.

5. Consideration of the possibility of a regression estimation method.

Within the first stage, data on the Russian SDG indicators for 2014-2019 were selected according to the statistical information base Rosstat [21], while the choice of indicators is largely due to the conditions for maximizing information content. Data were taken for the following Sustainable Development Goals:

1. Ensuring inclusive and equitable quality education and promoting the lifelong learning opportunities for all (SDG4)

2. Ensuring the healthy lifestyles and promoting the well-being for all at all ages (SDG3).

3. Promotion to sustained, inclusive and sustainable economic growth, full and productive employment and decent work for all (SDG8).

4. Creation of resilient infrastructure, promotion of inclusive and sustainable industrialization and innovation (SDG9).

5. Ensuring openness, security, resilience and environmental sustainability of cities and human settlements (SDG11).

Since the indicators of goals are expressed in different units of measurement, the normalization method is used to bring them to a single assessment scale. The transition to the $[0 ; \mathrm{N}]$-point scale, where 0 is the lowest indicator, $\mathrm{N}$ is the highest indicator, was carried out according to the formula [S.A. Ayvazyan, p. 84]:

$$
\tilde{x}=\frac{x-x_{\min }}{x_{\max }-x_{\min }} * N \text {, }
$$

where $x_{\max }$ и $x_{\min }$ - the maximum and minimum values of the initial indicator, respectively.

This formula is applicable in cases where the initial indicator is related $x$ with the integral property of the analyzed category of monotonically increasing dependence. When connected with a monotonically decreasing dependence, i.e., the smaller the value $x$, the worse the situation corresponding to the variable, the following formula is used:

$$
\tilde{x}=\frac{x_{\max }-x}{x_{\max }-x_{\min }} * N
$$

The selected SDG indicators with the applied normalization formula are provided in Table 1: 
Table 1. Selected SDG indicators with a description of the trend (dependency) and assignment of a variable designation.

\begin{tabular}{|c|c|c|c|c|}
\hline Target & Designation & Indicator & Dependence & $\begin{array}{c}\text { Normalization } \\
\text { rule }\end{array}$ \\
\hline \multirow{4}{*}{ SDG4 } & P1 & $\begin{array}{c}\text { Net coverage of } \\
\text { children under } 3 \text { years } \\
\text { with preschool } \\
\text { education }\end{array}$ & $\begin{array}{l}\text { Monotonically } \\
\text { increasing }\end{array}$ & (1) \\
\hline & P2 & $\begin{array}{l}\text { Gross enrollment ratio } \\
\text { of educational } \\
\text { programs of secondary } \\
\text { vocational education } \\
\text { - programs for } \\
\text { training mid-level } \\
\text { specialists } \\
\end{array}$ & $\begin{array}{l}\text { Monotonically } \\
\text { increasing }\end{array}$ & (1) \\
\hline & $\mathbf{P 3}$ & $\begin{array}{l}\text { Gross enrollment ratio } \\
\text { of educational } \\
\text { programs of higher } \\
\text { education - } \\
\text { bachelor's, specialist's, } \\
\text { master's programs }\end{array}$ & $\begin{array}{l}\text { Monotonically } \\
\text { increasing }\end{array}$ & (1) \\
\hline & P4 & $\begin{array}{l}\text { The proportion of } \\
\text { graduates with } \\
\text { disabilities in } 9 \text { and } \\
11 \text { classes covered by } \\
\text { vocational guidance in } \\
\text { the total number of } \\
\text { graduates with } \\
\text { disabilities }\end{array}$ & $\begin{array}{l}\text { Monotonically } \\
\text { increasing }\end{array}$ & (1) \\
\hline \multirow{3}{*}{ SDG3 } & P1 & $\begin{array}{l}\text { Sanitary state of } \\
\text { drinking water supply, } \\
\text { the number of samples } \\
\text { (from the distribution } \\
\text { network) that do not } \\
\text { meet hygienic } \\
\text { standards as a } \\
\text { percentage of the total } \\
\text { number of samples } \\
\text { examined }\end{array}$ & $\begin{array}{l}\text { Monotonically } \\
\text { decreasing }\end{array}$ & (2) \\
\hline & P2 & $\begin{array}{l}\text { Sanitary state of } \\
\text { atmospheric air, the } \\
\text { number of samples } \\
\text { that do not meet } \\
\text { hygienic standards as } \\
\text { a percentage of the } \\
\text { total number of } \\
\text { samples examined } \\
\text { (urban population) }\end{array}$ & $\begin{array}{l}\text { Monotonically } \\
\text { decreasing }\end{array}$ & (2) \\
\hline & P3 & $\begin{array}{c}\text { Soil sanitary } \\
\text { condition, number of } \\
\text { samples not meeting } \\
\text { hygienic standards as } \\
\text { a percentage of the } \\
\text { total number of } \\
\text { examined samples }\end{array}$ & $\begin{array}{l}\text { Monotonically } \\
\text { decreasing }\end{array}$ & (2) \\
\hline
\end{tabular}


Continuation of table 1.

\begin{tabular}{|c|c|c|c|c|}
\hline \multirow{4}{*}{ SDG8 } & P1 & $\begin{array}{c}\text { Consumption of fuel } \\
\text { and energy resources } \\
\text { per person employed } \\
\text { in the country's } \\
\text { economy }\end{array}$ & $\begin{array}{l}\text { Monotonically } \\
\text { decreasing }\end{array}$ & (2) \\
\hline & P2 & $\begin{array}{l}\text { Aggregate indicator of } \\
\text { the unemployment rate } \\
\text { and potential labor } \\
\text { force by sex for the } \\
\text { constituent entities of } \\
\text { the Russian Federation } \\
\text { in 2010-2016 }\end{array}$ & $\begin{array}{l}\text { Monotonically } \\
\text { decreasing }\end{array}$ & (2) \\
\hline & P3 & $\begin{array}{l}\text { Index of physical } \\
\text { volume of gross } \\
\text { domestic product per } \\
\text { capita for the year } \\
\text { preceding the previous } \\
\text { one } \\
\end{array}$ & $\begin{array}{l}\text { Monotonically } \\
\text { increasing }\end{array}$ & (1) \\
\hline & P4 & $\begin{array}{l}\text { The employment rate } \\
\text { of the population in } \\
\text { the constituent entities } \\
\text { of the Russian } \\
\text { Federation in 2010- } \\
2019 \\
\text { (based on data from a } \\
\text { sample labor force } \\
\text { survey) }\end{array}$ & $\begin{array}{l}\text { Monotonically } \\
\text { increasing }\end{array}$ & (1) \\
\hline \multirow{5}{*}{ SDG9 } & P1 & $\begin{array}{l}\text { Inventive activity rate } \\
\text { (number of domestic } \\
\text { patent applications for } \\
\text { inventions filed in } \\
\text { Russia per } 10 \\
\text { thousand population) }\end{array}$ & $\begin{array}{l}\text { Monotonically } \\
\text { increasing }\end{array}$ & (1) \\
\hline & P2 & $\begin{array}{l}\text { Share of researchers } \\
\text { under the age of } 39 \text { in } \\
\text { the total number of } \\
\text { Russian researchers }\end{array}$ & $\begin{array}{l}\text { Monotonically } \\
\text { increasing }\end{array}$ & (1) \\
\hline & P3 & $\begin{array}{l}\text { Internal R\&D costs } \\
\text { from all sources }\end{array}$ & $\begin{array}{c}\text { Monotonically } \\
\text { increasing }\end{array}$ & (1) \\
\hline & P4 & $\begin{array}{l}\text { Researchers (full-time } \\
\text { equivalent) per million } \\
\text { inhabitants }\end{array}$ & $\begin{array}{l}\text { Monotonically } \\
\text { increasing }\end{array}$ & (1) \\
\hline & P5 & $\begin{array}{l}\text { Research and } \\
\text { development } \\
\text { expenditures as a } \\
\text { percentage of the } \\
\text { gross domestic } \\
\text { product of the Russian } \\
\text { Federation }\end{array}$ & $\begin{array}{l}\text { Monotonically } \\
\text { increasing }\end{array}$ & (1) \\
\hline
\end{tabular}


Continuation of table 1 .

\begin{tabular}{|c|c|c|c|c|}
\hline \multirow{4}{*}{ SDG11 } & P1 & $\begin{array}{c}\text { Number of the } \\
\text { population living in } \\
\text { unfavorable } \\
\text { environmental } \\
\text { conditions (in cities } \\
\text { with high and very } \\
\text { high levels of air } \\
\text { pollution (air pollution } \\
\text { index is more than 7)) }\end{array}$ & $\begin{array}{c}\text { Monotonically } \\
\text { decreasing }\end{array}$ & (2) \\
\hline & P2 & $\begin{array}{l}\text { Funds allocated for } \\
\text { conservation of } \\
\text { cultural heritage sites }\end{array}$ & $\begin{array}{l}\text { Monotonically } \\
\text { increasing }\end{array}$ & (1) \\
\hline & P3 & $\begin{array}{l}\text { The share of the area } \\
\text { of green space within } \\
\text { the city limits to the } \\
\text { total area of urban } \\
\text { land within the city } \\
\text { limits }\end{array}$ & $\begin{array}{l}\text { Monotonically } \\
\text { increasing }\end{array}$ & (1) \\
\hline & P4 & $\begin{array}{l}\text { Funds have actually } \\
\text { been spent on } \\
\text { preservation of } \\
\text { cultural heritage sites }\end{array}$ & $\begin{array}{l}\text { Monotonically } \\
\text { increasing }\end{array}$ & (1) \\
\hline
\end{tabular}

Normalization of SDG4 indicators is provided in Table 2.

Table 2. Normalization of SDG4 indicators, 2015-2019, across the Russian Federation.

\begin{tabular}{|l|l|c|c|c|c|c|}
\hline & & P1 & P2 & P3 & P4 & II \\
\hline 2015 & \multirow{5}{*}{2016} & 0.198 & 1.387 & 0.682 & 0.000 & 2.267 \\
\cline { 1 - 5 } 2017 & \multirow{4}{*}{ Russian Federation } & 0.495 & 1.387 & 0.000 & 0.598 & 2.480 \\
\cline { 4 - 7 } & & 0.890 & 1.849 & 0.682 & 1.197 & 4.618 \\
\cline { 4 - 7 } 2018 & & 1.531 & 2.165 & 2.011 & 1.795 & 7.504 \\
\cline { 4 - 7 } & & 2.500 & 2.500 & 0.929 & 2.500 & 8.429 \\
\hline
\end{tabular}

Performing normalization allows to go to the next step - the calculation of the integral value with assignment of weights to the variables. For this, a weighted sum was used:

$$
Y=\sum_{j=1}^{n} w_{j} \tilde{x}^{(j)},
$$

where $\tilde{x}^{(j)}$ - normalized variables;

$w_{j}$ is the expertly assigned weight of the variable.

Since the indicators included in each of the Goals are equal for achieving the SDGs, weights were assigned in such a way that, in total, each goal has a weight of one:

Table 3. Weighted values with assignment for each SDG indicator considering the equivalence.

\begin{tabular}{|c|c|c|}
\hline Target & Indicator & Weight \\
\hline \multirow{4}{*}{ SDG4 } & P1 & 0.25 \\
\cline { 2 - 3 } & P2 & 0.25 \\
\cline { 2 - 3 } & P3 & 0.25 \\
\cline { 2 - 3 } & $\mathbf{P 4}$ & 0.25 \\
\hline
\end{tabular}

\begin{tabular}{|c|c|c|}
\hline Target & Indicator & Weight \\
\hline \multirow{4}{*}{ SDG9 } & P1 & 0.2 \\
\cline { 2 - 3 } & P2 & 0.2 \\
\cline { 2 - 3 } & P3 & 0.2 \\
\cline { 2 - 3 } & $\mathbf{P 4}$ & 0.2 \\
\hline
\end{tabular}


Continuation of table 3 .

\begin{tabular}{|c|c|c|}
\multirow{4}{*}{ SDG3 } & P1 & 0.33 \\
\cline { 2 - 3 } & P2 & 0.34 \\
\cline { 2 - 3 } & P3 & 0.33 \\
\hline \multirow{4}{*}{ SDG8 } & P1 & 0.25 \\
\cline { 2 - 3 } & $\mathbf{P 2}$ & 0.25 \\
\cline { 2 - 3 } & $\mathbf{P 3}$ & 0.25 \\
\cline { 2 - 3 } & $\mathbf{P 4}$ & 0.25 \\
\hline
\end{tabular}

\begin{tabular}{|c|c|c|} 
& P5 & 0.2 \\
\hline \multirow{4}{*}{ SDG11 } & P1 & 0.25 \\
\cline { 2 - 3 } & P2 & 0.25 \\
\cline { 2 - 3 } & P3 & 0.25 \\
\cline { 2 - 3 } & P4 & 0.25 \\
\hline
\end{tabular}

\section{Study Results}

The integral indicators obtained within the calculation form the basis for the correlation analysis of the SDG interconnections. The values of the SDG4 integral indicator for 20152019 are shown in Fig. 1.

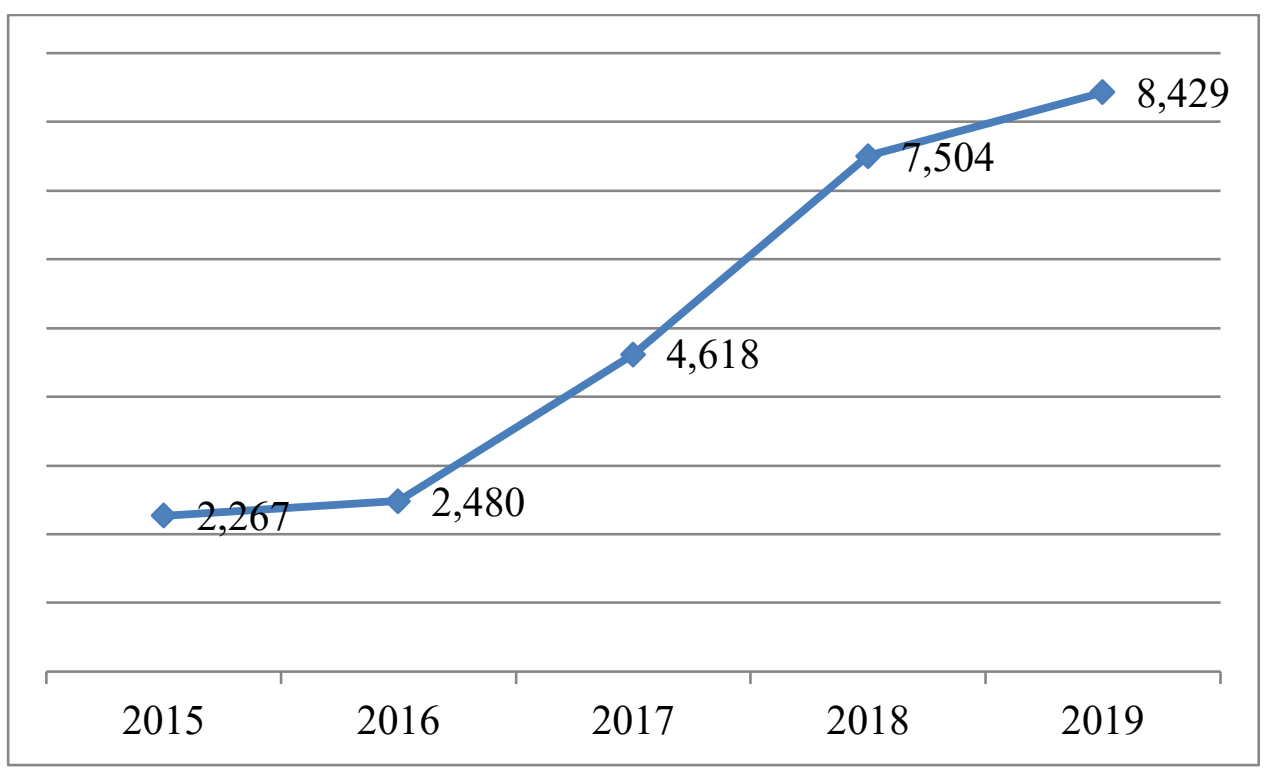

Fig. 1: Integrated indicator of SDG4, 2015-2019.

To assess the relationship between SDG4 and the rest of the selected Sustainable Development Goals, a correlation analysis was carried out, the results of which make it possible to assess the degree of closeness of the relationship between the obtained integral values. In this case, with the observed positive correlation, both values of the variables increase or decrease proportionally. A negative linear correlation is characterized by an increase in one variable and a decrease in another, and vice versa. The correlation coefficient is a value ranging from -1 to +1 , where 0 is defined as the independence of both variables from each other. 
Table 4. Correlation analysis of SDG indicators based on 2015-2019 data.

\begin{tabular}{|c|r|r|r|r|r|}
\hline & \multicolumn{1}{|c|}{ SDG4 } & \multicolumn{1}{c|}{ SDG3 } & \multicolumn{1}{c|}{ SDG8 } & \multicolumn{1}{c|}{ SDG9 } & \multicolumn{1}{c|}{ SDG11 } \\
\hline SDG4 & 1 & & & & \\
\hline SDG3 & 0,9796 & 1 & & & \\
\hline SDG8 & -0.4906 & -0.4369 & 1 & & \\
\hline SDG9 & -0.9282 & -0.9683 & 0.2393 & 1 & \\
\hline SDG11 & -0.0922 & -0.2092 & 0.4752 & 0.0789 & 1 \\
\hline
\end{tabular}

The dynamics of the integral values of the Sustainable Development Goals and the direction of their changes are shown in Fig. 2.

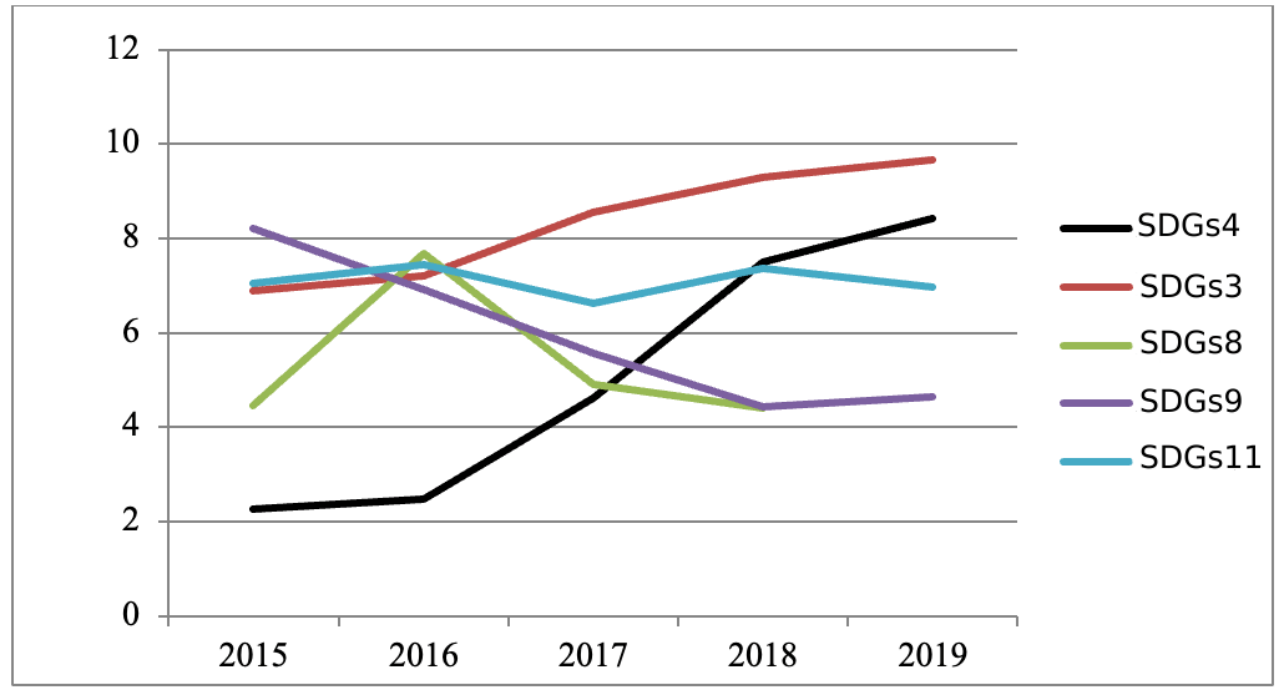

Fig. 2: Dynamics of the Sustainable Development Goals, 2015-2019.

A more detailed analysis of SDG9 revealed unobvious results regarding the correlation between individual indicators of the share of researchers under the age of 39 in the total number of Russian researchers and the number of researchers per million inhabitants, the value of which is -0.9879 , which is the basis for the assertion of a negative relationship. Figure 3 shows the opposite dynamics of indicators from 2010 to 2019. 


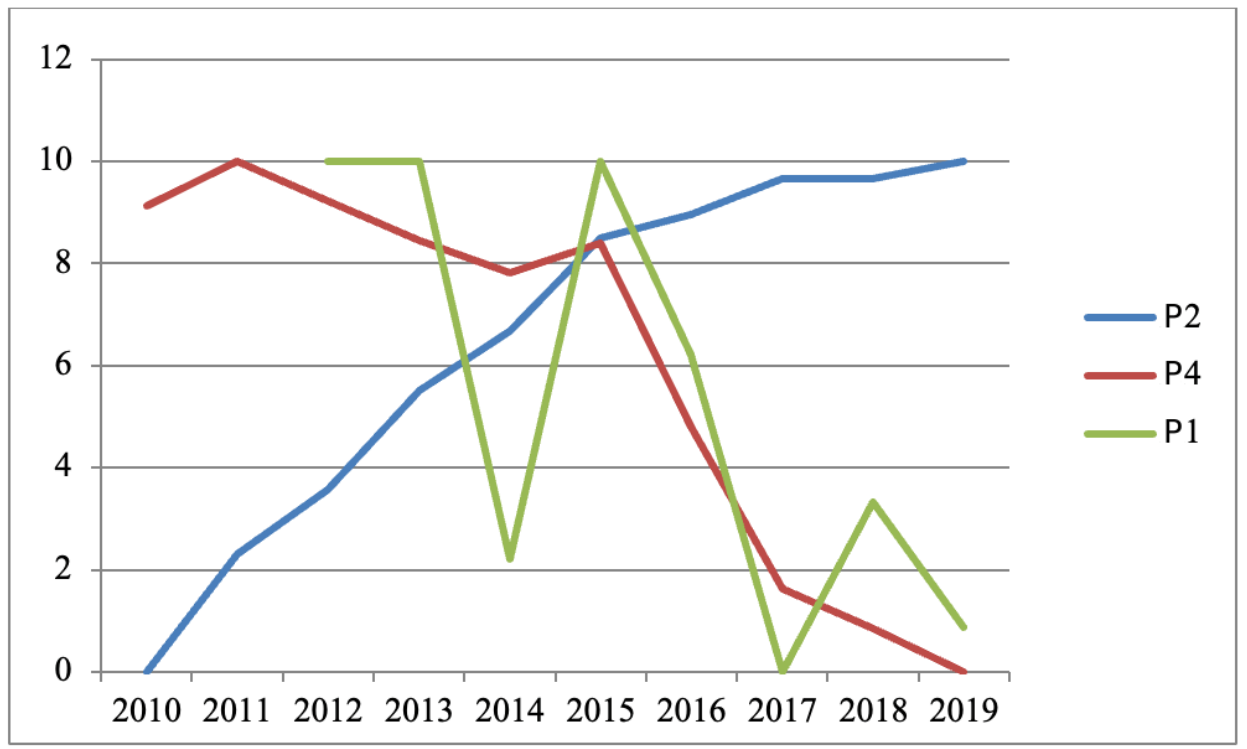

Fig. 3. The trend of change in the values of indicators P1, P2, P4, 2010-2019.

P1: Coefficient of inventive activity (the number of domestic patent applications for inventions filed in Russia per 10 thousand people);

P2: Share of researchers under the age of 39 in the total number of Russian researchers;

P4: Researchers (full-time equivalent) per million inhabitants.

Using the method of correlation analysis, it was found that not all Sustainable Development Goals have a close relationship, therefore, it is possible to use regression analysis as an estimate of dependent and independent variables. In this case, the dependent or explained variable will be SDG4, independent explanatory variables - SDG8 and SDG9 as factors that have a weak correlation with each other. The regression model by the method of S.A. Ayvazyan [S.A. Ayvazyan, p. 86] is as follows:

$$
Y(t)=\beta_{0}+\beta_{1} X_{1}(t)+\beta_{2} X_{2}(t)+\varepsilon,
$$

where $Y(t)$ - an integral indicator of achieving the Sustainable Development Goals in year $t$;

$X_{n}(t)$ - variables with $(t)$ - number of points in time (the availability of data for 20152018 assumes 4 values). $X 1$ - promoting inclusive and sustainable economic growth, full and productive employment and decent work for all (SDG8), $X 2$ - creation of resilient infrastructure, promotion of inclusive and sustainable industrialization and innovation (SDG9).

$\beta_{n}$ - regression coefficients;

$\varepsilon$-indicator of influence on $Y$ of unaccounted for variables is random.

Then the regression model specifying the factors would take the following form:

$$
Y(t)=14,723-0,441 X_{1}(t)-1,297 X_{2}(t),
$$

where the coefficient of determination $R^{2}$ being a reflection of the proportion of variation in the effective attribute of the dependent variable under the influence of factors, it is equal to $95.76 \%$ and determines the presence of a relationship between the variables. 


\section{Discussion}

Correlation analysis revealed a strong link between the Goals of ensuring inclusive and equitable quality education and promoting lifelong learning opportunities for all (SDG4) and ensuring healthy lifestyles and promoting well-being for all at all ages (SDG3), whose set of indicators for the latter was the sanitary state of drinking water supply, atmospheric air and soil (a relation equal to 0.9796). Conventionally, SDG3 was presented as an indicator that reveals the ecological component in the context of this study. Based on the result provided in Figure 2, the SDG3 indicator, starting from 2015, has a positive growth trend. Among the reasons for this trend, one can single out the effective implementation of the Federal Law on environmental education of the population [25], while today the topic of greening education in the interests of sustainable development of society is gaining great interest [G.M. Abdurakhmanov, 2017], [A.A. Niyazova, 2021]. In addition, the continuous development and implementation of innovative technologies in the production sector contributes to a more productive use and handling of natural and material resources.

A different result is observed when analyzing the correlation between SDG4 and the Goal on creation of resilient infrastructure, promoting inclusive and sustainable industrialization and innovation (SDG9), where there is a high feedback (-0.9282). Among the set of indicators for SDG9, we were most interested in indicators characterizing the area of research development. The abrupt dynamics of growth in the values of this Goal, starting from 2015, indicates a decrease in the coefficient of inventive activity - a decrease in the number of patent applications for inventions filed in Russia. The observed feedback between the Goals raises a lot of questions regarding the quality of preschool, primary, secondary and higher professional education at the national level, as well as the likely migration of highly qualified specialists abroad. Moreover, according to Figure 3, the increasing share of researchers under the age of 39 in the total number of Russian researchers and the decreasing number of researchers, showing a high inverse interdependence, may become the basis for confirming the hypothesis about the migration of young specialists after achieving high results in professional activity in Russia.

A similar result is observed when analyzing the results of the correlation between SDG4 and the Goal of promoting progressive, inclusive and sustainable economic growth, full and productive employment and decent work for all (SDG8), which can be roughly designated as an economic component. Considering the feedback between the Goals (-0.4906) found in the study, with an increase in the values of education - SDG4, the indicators of the economic sector will, on average, have a negative trend. This implies the need for a more in-depth and detailed study of the reasons for decline in economic performance, including careful consideration of possible hidden gaps in education and the transparency of these problems in monitoring and data collection.

\section{Conclusion}

Improving the quality of education is an urgent issue for all countries of the world, since education strategies and activities within the framework of this Goal are based on ensuring that the population achieves a recognized level of competence in various fields, which is the basis for decision-making and active participation in solving global problems. Effective implementation of SDG4 is key to successfully achieving all of the Sustainable Development Goals.

Assessment of the relationship between the achievement of the Sustainable Development Goals showed the presence of an impact and relationship between education and the environmental, economic and innovation components. It is important to consider the need 
for a detailed study of methods for their implementation in order to comprehensively achieve the Sustainable Development Goals until 2030.

Despite the ambiguous nature of the dynamics of some of the Sustainable Development Goals, an increasing trend can be seen for the rest of the indicators (SDG3, SDG4), which generally indicates their effective implementation. Correlation analysis made it possible to summarize and disclose data on implementation of the Goals in the best way, given the lack of quantitative data on many of the indicators, and, as a consequence, their limited selection. The findings of the study are remarkable for their experimental approach to assessing the achievement of the Sustainable Development Goals and their interrelationships.

\section{References}

1. E. B. Barbier, The Sustainable Development Goals and the systems approach to sustainability, Economics E-Journal, 11, 1-22 (2017)

2. A. Diemer, SDG 4 "Quality Education", the Cornerstone of the SDGs: Case Studies of Pakistan and Senegal, Journal of Economics and Development Studies, 8, 9-32 (2020)

3. A. W. Lawrence, Macro-Level Studies of Direct and Indirect Relationships between SDG 4 and the 16 SDGS, Modern Economy, 11, 1176-1179 (2020)

4. S. Mondal, Performance Grading, Innovation and SDG 4 Relationships (Red'shine Publishing, 2021)

5. O. Saito, Sustainability science and implementing the sustainable development goals, Sustainability Science, 12, 1-4 (2017)

6. L. Raitskaya, Education for Sustainable Development: Glocal Implications for Universities, 7, 4-14 (2021)

7. G. M. Abdurahmanov, Obrazovanie v ustojchivom razvitii kak osnova formirovaniya ekologicheskogo mirovozzreniya, Yug Rossii: ekologiya, razvitie, 3, 115-137 (2017)

8. M. V. Agranovich, Indikatory dostizheniya celej ustojchivogo razvitiya $v$ sfere obrazovaniya i nacional'naya obrazovatel'naya politika, Voprosy obrazovaniya, 4, 242264 (2017)

9. S. A. Ajvazyan, Analiz kachestva i obraza zhizni naseleniya (2012)

10. S. N. Bobylev, Celi ustojchivogo razvitiya dlya budushchego Rossii, Problemy prognozirovaniya, 1, 26-33 (2017)

11. T. V. Gavrilova, Principy $i$ metody issledovaniya kachestva zhizni naseleniya, Tekhnologii kachestva zhizni, 2, 1-11 (2000)

12. A. M. Grzhibovskij, Korrelyacionnyj analiz, Ekologiya cheloveka, 9, 50-60 (2008)

13. Inklyuzivnost' i obrazovanie. Vsemirnyj doklad po monitoringu obrazovaniya (UNESCO, 2020)

14. V. I. Kamyshanov, Kachestvennoe obrazovanie - odna iz 17 celej ustojchivogo razvitiya OON, Etnodialogi, 1, 27-36 (2016)

15. O. L. Kuznecov, B. E. Bol'shakov, Ustojchivoe razvitie: Nauchnye osnovy proektirovaniya $v$ sisteme priroda-obshchestvo-chelovek: Uchebnik (2001)

16. T. A. Lan'shina, Opyt lokalizacii $i$ vnedreniya Celej ustojchivogo razvitiya v stranahliderah $v$ dannoj sfere, Vestnik mezhdunarodnyh organizacij: obrazovanie, nauka, novaya ekonomika, 1, 207-224 (2019)

17. A. M. R. Linders, Voprosy cifrovogo razvitiya i Celi ustojchivogo razvitiya OON, Kaspijskij region: politika, ekonomika, kul'tura, 3, 124-129 (2020) 
18. A. A. Malcev, Cifrovizaciya ekonomiki v kontekste realizacii Celej ustojchivogo razvitiya: obzor klyuchevyh ekspertnyh dokladov $2019 \mathrm{~g}$, Vestnik mezhdunarodnyh organizacij: obrazovanie, nauka, novaya ekonomika, 4, 189-195 (2020)

19. N. M. Milovanceva, Monitoring progressa v dostizhenii CUR OON po doshkol'nomu obrazovaniyu: vazhnyj shag dlya obespecheniya spravedlivosti $i$ ustojchivosti nacional'nyh ekonomik, Vestnik mezhdunarodnyh organizacij: obrazovanie, nauka, novaya ekonomika, 4, 122-143 (2018)

20. A. A. Niyazova, Nepreryvnoe social'no-ekologicheskoe obrazovanie budushchego uchitelya $v$ interesah ustojchivogo razvitiya obshchestva, Perspektivy nauki i obrazovaniya, 4, 147-159 (2021)

21. O Celyah ustojchivogo razvitiya: dannye po pokazatelyam CUR (Rosstat, 2021)

22. A. G. Saharov, Perspektivy realizacii Celej ustojchivogo razvitiya OON v Rossii, Vestnik mezhdunarodnyh organizacij: obrazovanie, nauka, novaya ekonomika, 14, 189206 (2019)

23. T. S. Smirnova, Problemy realizacii celej ustojchivogo razvitiya v Rossii, Moskovskij ekonomicheskij zhurnal, 8, 21-31 (2019)

24. E. G. Spodareva, Primenenie korrelyacionno-regressionnogo analiza dlya ocenki finansovoj ustojchivosti predpriyatiya, Vestnik Ural'skogo instituta ekonomiki, upravleniya i prava, 4, 27-35 (2020)

25. Federal'nyj zakon ot 10.01.2002 N 7-FZ "Ob ohrane okruzhayushchej sredy" (2021) 